\title{
Spatial distribution of fish assemblages along environmental gradients in the temporary ponds of Northern Pantanal, Brazil
}

\author{
Karina K. TONDATO,${ }^{1}$ Ibraim FANTIN-CRUZ, ${ }^{2 *}$ Olavo C. PEDROLLO, ${ }^{2}$ Yzel R. SÚAREZ ${ }^{3}$ \\ ${ }^{1}$ Departamento de Zoologia, Universidade Federal do Rio Grande Sul, Av. Bento Gonçalves 9500, 91501-970, Porto Alegre, Brazil; \\ ${ }^{2}$ Instituto de Pesquisas Hidráulicas, Universidade Federal do Rio Grande do Sul, Av. Bento Gonçalves 9500, 91501-970, Porto \\ Alegre, Brazil; ${ }^{3}$ Centro Integrado de Análise e Monitoramento Ambiental, Laboratório de Ecologia, Universidade Estadual de Mato \\ Grosso do Sul, Rod. Dourados-Itahum, km 12, 79804-970, Dourados, Brazil. \\ *Corresponding author: ibraimfantin@gmail.com
}

\begin{abstract}
Ten temporary ponds in Northern Pantanal were studied in July 2006 to explore whether a spatial distribution pattern existed in the composition of fish assemblages, and to identify which environmental variables determined their distribution. The existence of any spatial pattern was tested using the multivariate Mantel correlogram, while the influence of environmental variables was quantified by a Canonical Correspondence Analysis (CCA). A total of 8735 individuals was sampled from 29 species, predominantly represented by Hyphessobrycon elachys and Serrapinnus calliurus. Composition of fish assemblages varied among ponds, but this variation had no significant spatial pattern for any of the distance classes considered, thus indicating that the species composition varied independently of the distance between ponds. This suggests that stochastic dispersal processes did not influence the spatial structure of species, as predicted by the neutral theory. Conversely, species composition in the ponds was determined by variables that included depth, macrophyte richness and cover. Species such as Markiana nigripinnis, Crenicichla vittata and Moenkhausia sanctaefilomenae occurred in deeper waters, while Parauchenipterus striatulus, Eigenmannia trilineata and Psellogrammus kennedyi were mainly associated with greater richness and macrophyte cover, as already demonstrated by the niche theory applied in ponds which tended to have similar characteristics and a similar fish composition.
\end{abstract}

Key words: pond depth, macrophyte, niche theory, neutral theory, spatial analysis, floodplain.

Received: March 2012. Accepted: August 2012.

\section{INTRODUCTION}

In recent decades, several studies of the spatial organisation of fish assemblages have shown that ecological patterns vary depending on space (Jackson et al., 2001; Tejerina-Garro and Mérona, 2001; Valério et al., 2007; Súarez et al., 2011). This spatial variation can be determined by environmental characteristics and interactions among species, as advocated by the niche theory (Hutchinson, 1957; Chase and Leibold, 2003), or by stochastic processes through random combinations of colonisation, as assumed by the neutral theory (Hubbell, 2001).

In floodplain aquatic environments, studies aiming to find spatial or temporal patterns in response to environmental variations indicated that fish assemblages are associated with macrophyte cover, habitat complexity and depth of water bodies (Mourão et al., 1988; Petry et al., 2003; Neiff et al., 2009; Maltchik et al., 2010), among other factors. Assemblages can also differ spatially because the hydrological connectivity among the different parts of the floodplain is limited by the distance between ponds and river channel (Pouilly and Rodríguez, 2003), and by the isolation time of the ponds (Súarez et al., 2001, 2004).
Regarding the organisation and structure of fish assemblages in temporary water bodies in floodplains, the influence of hydroperiod (i.e., the duration time of ponds), depth, connection, and distance between water bodies have been recognised (Baber et al., 2002; Pazin et al., 2006; Fernandes et al., 2010a). These factors describe the increasing isolation of water bodies, which in turn increases fish density and reduces migration (Scarabotti et al., 2011). This may also result in assemblages with different composition, as a consequence of different probabilities of colonisation and extinction of each species (Pazin et al., 2006). In addition, stronger biotic interactions, e.g. competition and predation (Rodríguez and Lewis 1994, 1997; Tejerina-Garro et al., 1998; Súarez et al., 2001), physiological stress (Winemiller et al., 2000), macrophyte cover and water transparency observed in permanent ponds (Scarabotti et al., 2011) may influence and regulate fish assemblages in temporary ponds. Hence, these communities may be shaped by deterministic environmental pathways (niche theory) (Lewis et al., 2000), or be structured by demographic stochasticity (neutral theory) (Hubbell, 2005), where the difference between these composition patterns is related to the dispersal ability of 
the individuals (McGill et al., 2006). Thus, closer assemblages should be more similar to one another than more distant ones (Gaston and Chown, 2005).

In northern Pantanal, a broad range of habitats is found in vegetation types within a distance of few tens of metres (Signor et al., 2010), influenced by flood dynamics (Fantin-Cruz et al., 2010). Still, the temporary water bodies or seasonally flooded plains in this region, especially those near the floodplain of Cuiabá river, have been receiving attention only recently. Some notable examples of research on this subject are the pioneering studies on microcrustaceans (Fantin-Cruz et al., 2008), aquatic invertebrates (Santos and Callil, 2010), fish fauna (Fernandes et al., 2010a, 2010b), and seed banks (Pagotto et al., 2011). Several fish species of temporary environments in this region have great importance since they are major food items for wading birds and so they contribute to maintain aquatic and terrestrial food webs. This notwithstanding, changes in topography (e.g., roads) and land use (e.g., pastures) alter the habitat structure and limit dispersion. Hence, they interfere with the biological cycle governed by flooding (Fernandes et al., 2010b). Knowledge of the structure of fish assemblages in temporary ponds and their relationships with other taxonomic groups (Hero et al., 2001) may show whether temporary systems are important for maintaining biodiversity in conservation strategies.

In this context, the study reported here was intended to show whether the distribution of composition of fish assemblages in temporary ponds of Cuiabá river floodplain agrees with the niche theory and/or the neutral the- ory predictions, by answering the following questions: i) is the composition of fish assemblages more similar in ponds close to each other than in distant ones? ii) do environmental variables determine the composition of fish assemblages in temporary ponds? Given the relevance of the niche theory for predicting the distribution of fish species, the structural characteristics of habitats are expected to determine the spatial distribution of the composition. Indeed, flooding can homogenise the species distribution.

\section{METHODS}

\section{Study area}

The study area is located in the floodplain of Cuiabá river, a part of northern Pantanal, in the municipality of Nossa Senhora do Livramento (State of Mato Grosso, Brazil) (Fig. 1). The region is flooded from December to March, when the ponds remain connected. From April onwards, water depth decreases, resulting in the loss of spatial connectivity of floodwaters and the formation of permanent/temporary ponds in depressions in the terrain. The temporary ponds of the sampled area are already monitored through projects related to the Long Term Program-PELD (Fantin-Cruz et al., 2008, 2010; Fernandes et al., 2010a, 2010b). Ponds are considered temporary when they have a predictable annual dry phase, usually of the order of 3-8 months (Collinson et al., 1995). In floodplains, the hydroperiod and the size of temporary ponds vary depending on the flood stage of the adjacent river.

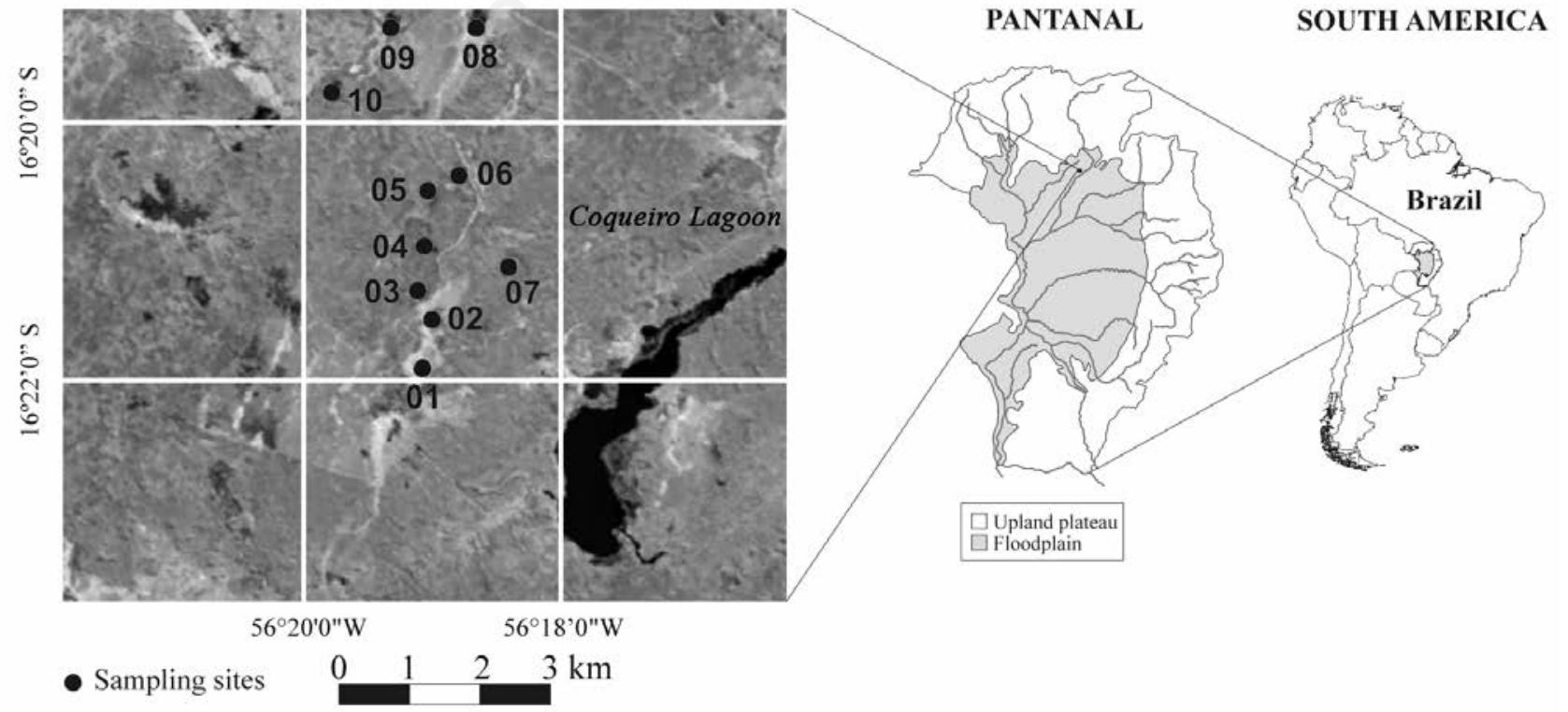

Fig. 1. Location of the temporary ponds in the floodplain of Northern Pantanal (Brazil). 
The flood has a mixed origin, being a combination of local rainfall and water overflow from Cuiabá river and its surroundings, whose flood regime is characterised by its low intensity (mean height of flood: $24 \mathrm{~cm}$ ) and long duration (mean: 85 days). The study area has a flat topography, varying from 112.52 to $116.56 \mathrm{~m}$, and has 4 phytophysiognomic units, the largest of which is the floodplain (Fantin-Cruz et al., 2010).

\section{Data collection and analysis}

Samples were collected from 10 temporary ponds (Fig. 1) in July 2006 during the dry season. Fish were collected using a rectangular sieve $(80 \times 120 \mathrm{~cm})$ with a mesh size of approximately $2 \mathrm{~mm}$. The sieve was cast three times below the macrophyte stands of each pond, randomly distributed in the pond and regardless of the depth. It was manoeuvred beneath the vegetation and raised to the surface to remove the captured species at each sampling point. The total capture of three sample units was defined as pond assemblage descriptors.

Fish specimens were fixed in 10\% formaldehyde and preserved in $70 \%$ ethanol for further identification and counting. Representative specimens were sent to the Laboratory of Fish Ecology and Resource Management of the Federal University of Mato Grosso. The species identification was based on Britski et al. (1999). Measurements of maximum depth, area, macrophyte richness and cover were taken in each pond. For interpretation purposes, pond water-depth was used as indicative of the hydroperiod. Indeed, another study in the region (Fantin-Cruz et al., 2010) showed that these two factors are closely related $\left(r^{2}=0.85\right)$. The area of each pond was estimated on the basis of its GPS (Garmin 76) coordinates. Each coordinate was then plotted using the software AutoCAD 2007 to calculate the area of each pond. The macrophyte cover was estimated from the total area occupied by all macrophyte stands in the pond, which was calculated using a measuring-tape in small ponds and GPS in larger ones. In this procedure, the percentage of macrophyte cover in each pond was determined from the ratio of total macrophyte area to pond area. Macrophyte richness was determined by scanning each pond and recording the number of occurring species.

The existence of a spatial pattern in the composition of fish assemblages (presence-absence data of the ponds) was analysed by a multivariate Mantel correlogram (Legendre and Fortin, 1989; Legendre, 1993). Significance was tested for each distance class using 999 random permutations, and it was established using the Bonferroni correction for multiple comparisons, $\mathrm{P}=0.05 / 5$ distance classes $=0.0125$. This analysis used the software SAM (Spatial Analysis in Macroecology) developed by Rangel et al. (2010).

A Canonical Correspondence Analysis [(CCA); Ter
Braak, 1986)] was used to quantify the influence of environmental variables (depth, area, macrophyte richness and cover) on the occurrence of all fish species (presence-absence data) in the assemblages analysed. The environmental variables were standardised $($ mean $=0$; variance $=1)$ to reduce the influence of descriptor scale on CCA results. This analysis used the software R ( R Development Core Team, 2011), with the CCA function of the Vegan package and the ENVFIT routine to determine the significance of the correlation of each environmental variable in the set of axes after 999 permutations. To simplify the visualisation of the results, only variables with a significant influence on the species will be presented and discussed.

\section{RESULTS}

A total of 8735 individuals were collected, distributed among 29 species belonging to the orders of Characiformes, Siluriformes, Perciformes, Gymnotiformes and Synbranchiformes (Tab. 1). The most abundant species was Hyphessobrycon elachys, with 4703 individuals (53.8\%) found in all ponds, followed by Serrapinnus calliurus, with 2709 individuals (31\%) captured in 9 ponds. Only 14 species, such as Aphyocharax paraguayensis and Aphyocharax anisitsi, occurred in more than three locations (Tab. 1).

As for the environmental variables, depth varied between 0.34 and $2.0 \mathrm{~m}($ mean $=1.00 \mathrm{~m} ; \mathrm{SD}=0.61)$, while the area varied from 387 to $4377 \mathrm{~m}^{2}$ (mean $=1591 \mathrm{~m}^{2}$; $\mathrm{SD}=1252$ ). Similarly, aquatic macrophytes richness ranged from 1 to 6 species (mean=3.6; SD=1.5), and macrophytes aquatic cover varied between 5 and $100 \%$ (mean=52.50\%; SD=33.35) (Tab. 2). The Mantel correlogram showed no evidence of spatial pattern in species composition among ponds, for any of the distance classes analysed (Fig. 2). This shows that species composition varies independently of the distance between the ponds.

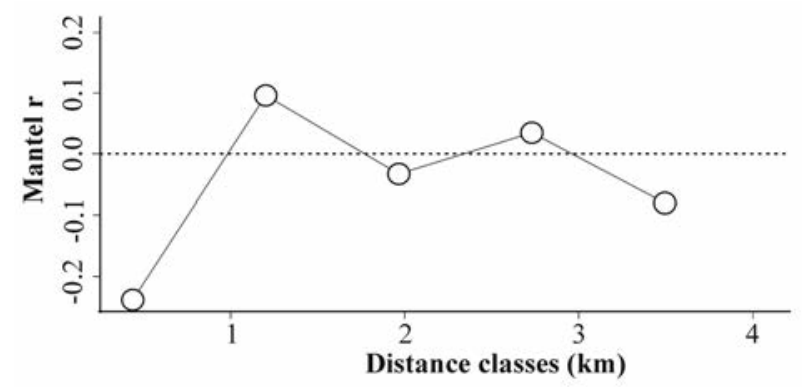

Fig. 2. Multivariate Mantel correlogram of the composition of fish species in the temporary ponds of Northern Pantanal (Brazil). Open circles indicate non-significant correlations $(\mathrm{P}>0.0125)$, after the Bonferroni correction. 
Tab. 1. List of fish species, occurrence, and abundance in the temporary ponds of the floodplain of Cuiabá river (Northern Pantanal, Brazil).

\begin{tabular}{|c|c|c|c|c|c|c|c|c|c|c|}
\hline \multirow[t]{2}{*}{ Order/Family/Species } & \multicolumn{9}{|c|}{ Temporary ponds } & \multirow[b]{2}{*}{10} \\
\hline & 1 & 2 & 3 & 4 & 5 & 6 & 7 & 8 & 9 & \\
\hline \multicolumn{11}{|l|}{ Characiformes } \\
\hline \multicolumn{11}{|l|}{ Acestrorhynchidae } \\
\hline Acestrorhynchus pantaneiro (Menezes, 1992) & - & - & - & - & - & - & 1 & - & - & - \\
\hline \multicolumn{11}{|l|}{ Characidae } \\
\hline Aphyocharax anisitsi (Eigenmann and Kennedy, 1903) & 3 & 7 & - & 32 & 13 & 4 & 39 & 7 & 8 & 43 \\
\hline Aphyocharax paraguayensis (Eigenmann, 1915) & 3 & 2 & - & 28 & 19 & 2 & 5 & 1 & 6 & 15 \\
\hline Astyanax abramis (Jenyns, 1842) & - & - & - & - & - & 2 & - & - & - & 2 \\
\hline Gymnocorymbus ternetzi (Boulenger, 1895) & - & - & 2 & - & 1 & - & 1 & 2 & 2 & 7 \\
\hline Hyphessobrycon elachys (Weitzman, 1984) & 464 & 100 & 674 & 2251 & 729 & 87 & 115 & 10 & 227 & 46 \\
\hline Hyphessobrycon eques (Steindachner, 1882) & - & - & - & - & - & - & 1 & - & - & 9 \\
\hline Markiana nigripinnis (Perugia, 1891) & - & - & 1 & - & - & - & - & - & - & - \\
\hline Moenkhausia dichroura (Kner, 1858) & - & 5 & - & - & - & 2 & - & 9 & - & 36 \\
\hline Moenkhausia sanctafilomenae (Steindachner, 1907) & - & - & - & - & - & 1 & - & - & - & 2 \\
\hline Serrapinnus calliurus (Boulenger, 1900) & 24 & 64 & - & 728 & 521 & 197 & 555 & 25 & 275 & 320 \\
\hline Serrapinnus microdon (Eigenmann, 1915) & - & - & - & - & 23 & - & - & - & - & - \\
\hline Psellogrammus kennedyi (Eigenmann, 1903) & - & 3 & - & - & - & 4 & 3 & - & 1 & 6 \\
\hline \multicolumn{11}{|l|}{ Crenuchidae } \\
\hline Characidium lateralis (Boulenger, 1895) & 4 & 1 & - & 8 & 25 & 5 & 2 & - & 20 & 4 \\
\hline \multicolumn{11}{|l|}{ Curimatidae } \\
\hline Curimatopsis myersi (Vari, 1982) & - & 4 & - & - & - & - & - & - & - & - \\
\hline \multicolumn{11}{|l|}{ Erythrinidae } \\
\hline Hoplerythrinus unitaeniatus (Spix and Agassiz, 1829) & - & - & - & 1 & - & - & - & - & - & - \\
\hline Hoplias malabaricus (Bloch, 1794) & - & - & 1 & 2 & - & - & - & - & - & - \\
\hline \multicolumn{11}{|l|}{ Lebiasinidae } \\
\hline Pyrrhulina australis (Eigenmann and Kennedy, 1903) & 3 & 10 & - & 31 & 8 & 7 & 10 & - & 19 & 14 \\
\hline
\end{tabular}

Siluriformes

Auchenipteridae

Parauchenipterus striatulus (Steindachner, 1876)

Callichthyidae

Callichthys callichthys (Linnaeus, 1758)

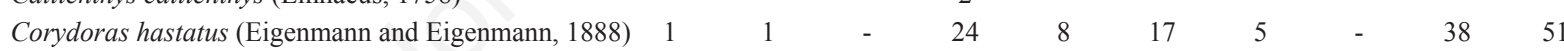
Lepthoplosternum pectorale (Boulenger, 1895)

Perciformes

Cichlidae

Aequidens plagiozonatus (Kullander, 1984)

Apistogramma borellii (Regan, 1906)

Crenicichla vittata (Heckel, 1840)

Laetacara dorsigera (Heckel, 1840)

$\begin{array}{cccccccccc}- & - & - & 3 & - & - & - & - & - & - \\ - & - & - & - & - & 12 & 3 & - & 2 & 43 \\ - & - & - & - & 1 & 1 & - & - & - & 3 \\ 36 & 110 & - & 14 & 37 & 33 & 77 & - & 118 & 123\end{array}$

Gymnotiformes

Hypopomidae

Brachyhypopomus sp.

Sternopygidae

Eigenmannia trilineata (Lopez and Castello, 1966)

Synbranchiformes

Synbranchidae

Synbranchus marmoratus (Bloch, 1795)

$9 \quad 11$

11


The first two axes of the CCA applied to data from the 10 temporary ponds explained $64.04 \%$ of the variation in species composition, with the first axis explaining $38.68 \%$, and the second, $25.36 \%$. The most important variables influencing species occurrence were: pond depth $\left(\mathrm{r}^{2}=0.60 ; \quad \mathrm{P}=0.01\right)$, macrophyte richness $\quad\left(\mathrm{r}^{2}=0.72\right.$; $\mathrm{P}=0.003)$ and cover $\left(\mathrm{r}^{2}=0.69 ; \mathrm{P}=0.007\right)$. Pond area $\left(\mathrm{r}^{2}=0.14 ; \mathrm{P}=0.51\right)$ was the only variable that did not influence variation in species composition. The species Markiana nigripinnis, Crenicichla vittata, and Moenkhausia sanctaefilomenae occurred in deeper ponds (Fig. 3). Hoplias malabaricus, Aequidens plagiozonatus and Symbranchus marmoratus were present in shallower environments and in more open areas. Parauchenipterus striatulus, Eigenmannia trilineata and Psellogrammus kennedyi were associated mainly with greater macrophyte richness and cover (Fig. 3).

\section{DISCUSSION}

The composition of fish assemblages in an environment results from the interaction between many environmental characteristics and biotic and biogeographic factors (Súarez and Petrere-Júnior, 2003; Hoeinghaus et al., 2007). Factors that influence the spatial distribution of fish species in streams (e.g., altitude, volume, flow and stream width: Oberdorff et al., 2001; Valério et al., 2007; Tondato and Súarez, 2010; Súarez et al., 2011) are different from those observed in floodplain ponds (Suarez et al., 2001, 2004). The composition of fish assemblages in temporary ponds of floodplains depends on multiple interactions with the environment: the occurrence of fish is uncommon during the isolation period because of drying out and limiting conditions (Baber et al., 2002) such as predation and competition for space (Okada et al., 2003). However, some species adapt and may survive for months in the absence of surface waters (Hart and Newman, 1995; Winemiller, 1996). Hence, the common occurrence of $\mathrm{Hy}$ pessobrycon, Serrapinnus, Astyanax and Hoplosternum littorale in this study - also verified by Okada et al. (2003) in temporary ponds in the dry season of the upper Paraná river (Brazil) - indicates a widespread adaptation and survival of these groups of species in ephemeral habitats subject to environmental stress. Also, the great abundance and widespread occurrence of Hyphessobrycon elachys and Serrapinnus calliurus shows that the stress caused by the drying process does not limit the successful occupation of these species in temporary ponds, as noted by Fernandes et al. (2010a) in the same region and by $\mathrm{Cu}-$ nico et al. (2002) in the upper Paraná river (Brazil). Moreover, the richness found in a single sampling represented almost 60\% (49 species and 1117 individuals) of the richness registered by Fernandes et al. (2010a) for the same region during a one-month collection using two methods (throw trap and gill net), thus emphasising the effective- ness of the sampling method for the study of fish fauna in rapid assessment of floodplain biodiversity.

For Pantanal ponds, Mourão et al. (1988) and Súarez et al. (2001, 2004), suggested that depth, isolation time, and distance from the river, associated with certain limnological characteristics, may determine fish species richness, dispersal and survival. However, in their spatial analysis, the distance between the ponds that influenced the colonisation process and the similarity between the environments had not been correlated with species composition. Therefore, the random distribution of fish species over the space showed that the connectivity between environments promoted by the flood does not result in ponds that are close to one other, as they are more similar in composition during the isolation period. This result supports the conclusions of Welcomme (1985), Rodríguez and Lewis (1997), Tejerina-Garro et al. (1998), and Pouilly and Rodríguez (2003) for ponds. These authors reported that the structure of fish assemblages often varies significantly among isolated water bodies, even when they are very close. Hence, the random spatial pattern showed that stochastic processes related to the dispersal limits have no significant effects on this distribution, in contrast with the neutral theory. According to this theory, indeed, species composition fluctuates randomly, and the composition is unpredictable at a local scale, only varying with geographical distance. It is noteworthy that the smallest distance class between the ponds (around $300 \mathrm{~m}$ ) can be low and insufficient to generate a spatial differentiation large enough to change the species composition. This happens because studies on composition of fish assemblages in ponds have varied in the scale used. Thus, Tejerina-Garro et al. (1998) - with a mean distance from the river of $2.9 \mathrm{~km}$ - and Súarez et al. $(2001,2004)$ - with distances varying from 0.1 to $34 \mathrm{~km}$ - found contradictory results, indicating that the isolation degree can be a major determinant of assemblage characteristics. Nevertheless, few studies quantified the length of spatial autocorrelation

Tab. 2. Environmental variables in the temporary ponds of Northern Pantanal (Brazil).

\begin{tabular}{lcccc}
\hline Ponds & $\begin{array}{c}\text { Depth } \\
(\mathrm{m})\end{array}$ & $\begin{array}{c}\text { Area } \\
\left(\mathrm{m}^{2}\right)\end{array}$ & $\begin{array}{c}\text { Macrophyte } \\
\text { richness }\end{array}$ & $\begin{array}{c}\text { Macrophyte } \\
\text { cover }(\%)\end{array}$ \\
\hline 1 & 0.37 & 2728 & 3 & 100 \\
2 & 0.34 & 534 & 5 & 60 \\
3 & 2.00 & 1947 & 4 & 15 \\
4 & 0.50 & 387 & 1 & 5 \\
5 & 1.40 & 1394 & 2 & 20 \\
6 & 1.50 & 630 & 3 & 70 \\
7 & 0.45 & 4377 & 5 & 80 \\
8 & 1.05 & 753 & 4 & 55 \\
9 & 0.70 & 992 & 6 & 90 \\
10 & 1.70 & 2173 & 3 & 30 \\
\hline
\end{tabular}


for fish composition in floodplains. Among them, Súarez et al. (2001) observed that in distant lagoons isolated for various periods, macrophyte cover and lagoon depth were the main determinants of species richness.

Furthermore, during the isolation period, the internal functioning factors that drive the local abiotic processes and interactions among species lead to a differentiation in the fish assemblages between ponds through a deterministic process (Scarabotti et al., 2011). Therefore, the absence of a spatial pattern in fish species composition suggests that local deterministic processes have created a meso-scale random distribution. In these water bodies, much of the composition can be determined by colonisation so that, although the colonisation process may be random, the species pool can be deterministic and predictable (Kodrick-Brown and Brown, 1993).

As a consequence, fish composition in temporary ponds, which was strongly associated with depth, richness and macrophyte cover, demonstrated that the fish fauna is not randomly distributed in relation to these factors, but rather it is determined by them, as predicted by the niche theory. Studies on temporary floodplain environments have verified that depth and hydroperiod are the main influential factors on the structure of the assemblages in these environments (Baber et al., 2002; Pazin et al., 2006; Fernandes et al., 2010a). This indicated that the influence of depth on composition is due not only to morphological and behavioural adaptations of the species, but also to the survival probability related to hydroperiod variation. Research by Fernandes et al. (2010a, 2010b) and Maltchik et al. (2010) also proved the influence of hydroperiod on fish composition in floodplains, showing that areas with a shorter hydroperiod had a composition different from those with a longer hydroperiod. The occurrence of Markiana nigripinnis, Crenicichla vittata and Moenkhausia sanctafilomenae was mainly limited by depth. Locations with greater depths (maximum of $2.0 \mathrm{~m}$ ) were preferred and they were probably selected during the flood period through colonisation (migration) before being retained when ponds became isolated. This preference may arise because deeper environments may have greater habitat complexity, supporting a higher number of fish species (Eadie et al., 1986; Pianka, 1994).

Besides depth, macrophyte richness and cover also influenced fish composition in ponds, showing the important association between macrophytes and structure of fish fauna in floodplains. The influence of macrophyte cover on the structure of fish assemblages was also observed by

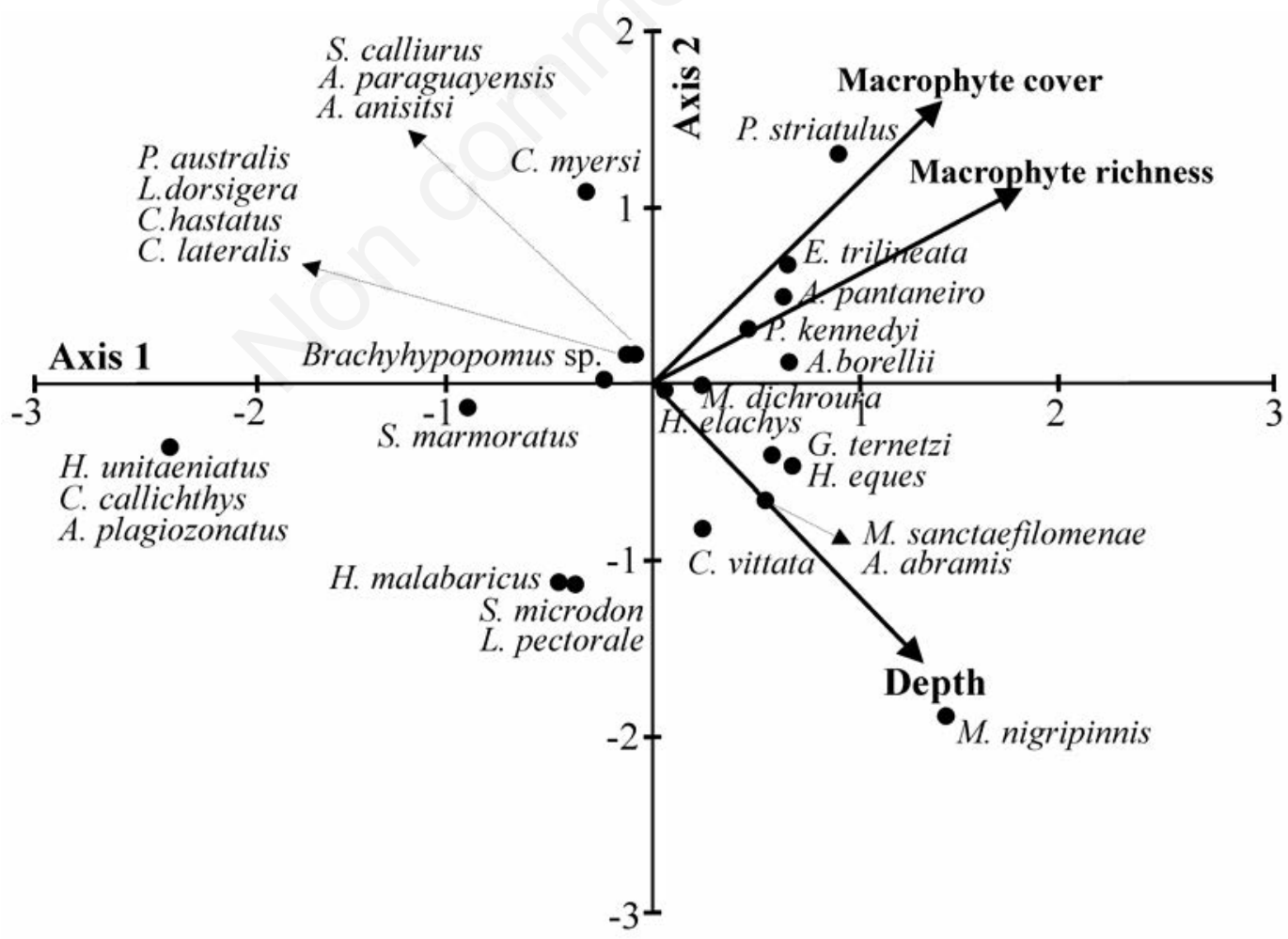

Fig. 3. Ordering of the Canonical Correspondence Analysis with the data of occurrence of fish species and the environmental characteristics of the ten temporary ponds sampled in Northern Pantanal (Brazil). 
Scarabotti et al. (2011), who stressed its local impact by regulating the predator-prey relationship that lead to changes in the assemblage composition. Consequently, Parauchenipterus striatulus, Eigenmannia trilineata and Psellogrammus kennedyi - strongly characterised by environments with large cover and high richness of macrophytes - may be related to a lower predation pressure and efficiency in the allocation of food resources. This relation is common for macrophytes play a key role in nutrient dynamics, contributing to the increase in structural heterogeneity of habitats, and influencing the biological diversity, interspecific relationships, and system productivity (Agostinho et al., 2003; Pelicice et al., 2005). Macrophytes are also one of the primary determinants of the structure of fish communities in lentic environments (Súarez et al., 2001 and 2004; Petry et al., 2003).

\section{CONCLUSIONS}

The distribution of fish fauna in temporary ponds was determined by depth, richness, and macrophyte cover, according to the deterministic niche theory, where ponds with similar characteristics tend to present a similar fish composition. The similarity in composition was also independent of the geographical distance between ponds, showing that stochastic dispersal processes had no influence on the spatial structure of species, as the neutral theory predicts. The distribution of fish assemblage composition in temporary ponds was therefore governed by deterministic processes, in accordance with the niche theory.

\section{ACKNOWLEDGMENTS}

The authors would like to thank the Graduate Program in Ecology and Conservation of Biodiversity (UFMT) for funding and providing logistic support, and Izaias M. Fernandes, Leandro Baginski, and Alexandro C. Florentino for the assistance in sorting the biological material. They also thank the National Council to Scientific and Technologic Development $(\mathrm{CNPq})$ for productivity grants to YRS.

\section{REFERENCES}

Agostinho AA, Gomes LC, Ferreira HJ Jr, 2003. [Relações entre macrófitas aquáticas e fauna de peixes], p. 261-279. [In Portuguese]. In: S.M. Thomaz, L.M. Bini (eds.) Ecologia e manejo de macrófitas aquáticas. EDUEM, Maringá, Brazil.

Baber JM, Childers DL, Babbitt KJ, Anderson DH, 2002. Controls on fish distribution and abundance in temporary wetlands. Can. J. Fish Aquat. Sci. 59:1441-1450.

Britski HA, Silimon KZ, Lopes BS, 1999. [Peixes do Pantanal. Manual de identificação]. [Book in Portuguese]. Embrapa - Serviço de Produção de Informação ed., Brasília, Brazil: $184 \mathrm{pp}$.

Chase JM, Leibold MA, 2003. Ecological niches: linking classical and contemporary approaches. University of Chicago Press, IL, USA: 216 pp.
Collinson NH, Biggs J, Corfield A, Hodson MJ, Walker D, Whitfield M, Williams PJ, 1995.Temporary and permanent ponds: an assessment of the effect of drying out on the conservation value of aquatic macroinvertebrates. Biol. Conserv. 74:125-133.

Cunico AM, Graça WJ, Veríssimo S, Bini LM, 2002. [Influência do nível hidrológico sobre a assembléia de peixes em lagoa sazonalmente isolada da planície de inundação do alto rio Paraná]. [Article in Portuguese]. Acta. Sci. Biol. Sci. 24:383-389.

Eadie JM, Hurly AT, Montgomerie RD, Teather KL, 1986. Lakes and rivers as islands: species-area relationships in the fish faunas of Ontario. Environ. Biol. Fish. 15:81-89.

Fantin-Cruz I, Girard P, Zeilhofer P, Collischonn W, Cunha CN, 2010. [Unidades fitofisionômicas em mesoescala no Pantanal Norte e suas relações com a geomorfologia]. [Article in Portuguese]. Biota Neotrop. 10:31-38.

Fantin-Cruz I, Tondato KK, Penha JMF, Mateus LAF, Girard P, Fantin-Cruz, I, 2008. Influence of fish abundance and macrophyte cover on microcrustacean density in temporary ponds of the Northern Pantanal-Brazil. Acta Limnol. Bras. 20:339-344.

Fernandes IM, Machado FA, Penha J, 2010a. Spatial pattern of a fish assemblage in a seasonal tropical wetland: effects of habitat, herbaceous plant biomass, water depth, and distance from species sources. Neotrop. Ichthyol. 8:289-298.

Fernandes IM, Zuanon J, Penha J, 2010b. [Peixes]. In: I.M. Fernandes, C.A. Signor, J. Penha (eds.) [Biodiversidade no Pantanal de Poconé]. [Book in Portuguese]. Attema ed., Cuiabá, Brazil: 196 pp.

Gaston KJ, Chown SL, 2005. Neutrality and the niche. Funct. Ecol. 19:1-6.

Hart R, Newman JR, 1995. The importance of isolated wetlands to fish and wildlife in Florida. Nongame Wildlife Program ed., Tallahassee, FL, USA: 145 pp.

Hero JM, Magnusson WE, Rocha CFD, Catterall CP, 2001. Antipredator defences influence the distribution of amphibian prey species in the Central Amazon Rain Forest. Biotropica 33:131-141.

Hoeinghaus DJ, Winemiller KO, Birnbaum JS, 2007. Local and regional determinants of stream fish assemblage structure: inferences based on taxonomic vs. functional groups. J. Biogeogr. 34:324-338.

Hubbell SP, 2001. The unified neutral theory of biodiversity and biogeography. Princeton University Press, NJ, USA: 448 pp.

Hubbell SP, 2005. Neutral theory in community ecology and the hypothesis of functional equivalence. Funct. Ecol. 19:166-172.

Hutchinson MF, 1957. Concluding remarks. Cold Spring Harb. Sym. 22:415-427.

Jackson DA, Peres-Neto PR, Olden JD, 2001. What controls who is where in freshwater fish communities - the roles of biotic, abiotic, and spatial factors. Can. J. Fish Aquat. Sci. 58:157-170.

Kodrick-Brown A, Brown JH, 1993. Highly structured fish communities in Australian desert springs. Ecology 74:18471855.

Legendre P, 1993. Spatial autocorrelation: trouble or new paradigm? Ecology 74:1659-1673.

Legendre P, Fortin MJ, 1989. Spatial pattern and ecological analysis. Vegetatio 80:107-138. 
Lewis WMJ, Hamilton SK, Lasi MA, Rodrígues M, Saunders JMI, 2000. Ecological determinism on the Orinoco floodplain. Bioscience 50:681-692.

Maltchik L, Lanés LEK, Stenert C, Medeiros ESF, 2010. Species-area relationship and environmental predictors of fish communities in coastal freshwater wetlands of southern Brazil. Environ. Biol. Fish. 88:25-35.

McGill BJ, Enquist BJ, Weiher E, Westoby M, 2006. Rebuilding community ecology from functional traits. Trends Ecol. Evol. 21:178-185.

Mourão GM, Ishii IH, Campos ZMS, 1988. [Alguns fatores limnológicos relacionados com a ictiofauna das baías e salinas do Pantanal da Nhecolândia]. [Article in Portuguese]. Acta Limnol. Bras. 11:181-198.

Neiff JJ, Poi de Neiff ASG, Verón MBC, 2009. The role of vegetated areas on fish assemblage of the Paraná River floodplain: effects of different hydrological. Neotrop. Ichthyol. 7:39-48.

Oberdorff T, Pont D, Hugueny B, Chessel D, 2001. A probabilistic model characterizing fish assemblages of French rivers: a framework for environmental assessment. Freshwater Biol. 46:399-415.

Okada EK, Agostinho AA, Petrere M Jr, Penczak T, 2003. Factors affecting fish diversity and abundance in drying ponds and ponds in the upper Paraná River basin, Brazil. Ecohydro. Hydrobiol. 3:97-110.

Pagotto MA, Silveira RML, Cunha CN, Fantin-Cruz I, 2011. Distribution of herbaceous species in the soil seed bank of a flood seasonality area, Northern Pantanal, Brazil. Int. Rev. Hydrobiol. 96:149-163.

Pazin VFV, Magnusson WE, Zuanon J, Mendonça FP, 2006. Fish assemblages in temporary ponds adjacent to 'terra firme' streams in Central Amazonia. Freshwater Biol. 51:1025-1037.

Pelicice FM, Agostinho AA, Thomaz SM, 2005. Fish assemblages associated with Egeria in a tropical reservoir: investigating the effects of plant biomass and diel period. Acta Oecol. 27:9-16.

Petry P, Bayley PB, Markele DF, 2003. Relationships between fish assemblages, macrophytes and environmental gradients in the Amazon River floodplain. J. Fish Biol. 63:547-579.

Pianka ER, 1994. Evolutionary ecology. $5^{\text {th }}$ ed. Harper Collins, New York, NY, USA: 486 pp.

Pouilly M, Rodríguez MA, 2003. Determinism of fish assemblage structure in neotropical floodplain lakes: influence of internal and landscape lake conditions, p. 243-265. In: R.L. Welcomme, T. Peter (eds.), Proc. $2^{\text {nd }}$ Int. Symp. on the Management of Large Rivers for Fisheries, Bangkok, Thailand.

R Development Core Team, 2011: R: A language and environment for statistical computing. R Foundation for Statistical Computing ed., Vienna, Austria.

Rangel TF, Diniz-Filho JAF, Bini LM, 2010. SAM: a comprehensive application for Spatial Analysis in Macroecology. Ecography 33:46-50.

Rodríguez MA, Lewis WMJ, 1994. Regulation and stability in fish assemblages of neotropical floodplain lakes. Oecologia 99:166-180.
Rodríguez MA, Lewis WMJ, 1997. Structure of fish assemblages along environmental gradients in floodplain lakes of the Orinoco River. Ecol. Monogr. 67:109-128.

Santos MT, Callil CT, 2010. [Invertebrados aquáticos], p. 5971. [in Portuguese]. In: I.M. Fernandes, C.A. Signor, J. Penha (eds.) [Biodiversidade no Pantanal de Poconé]. Attema ed., Cuiabá, Brazil.

Scarabotti PA, López JA, Pouilly M, 2011. Flood pulse and the dynamics of fish assemblage structure from neotropical floodplain lakes. Ecol. Freshw. Fish. 20:605-618.

Signor CA, Fernandes IM, Penha JO, 2010. [Pantanal e o sistema de pesquisa], p. 13-23. In: I.M. Fernandes, C.A. Signor, J. Penha (eds.) [Biodiversidade no Pantanal de Poconé]. Attema ed., Cuiabá, Brasil.

Súarez YR, de Souza MM, Ferreira FS, Pereira MJ, da Silva EA, Ximenes LQL, Gonçalves de Azevedo L, Martins OC, Lima SE Jr, 2011. Patterns of species richness and composition of fish assemblages in streams of the Ivinhema River basin, Upper Paraná River. Acta Limnol. Bras. 23:177-188.

Súarez YR, Petrere M Jr, 2003. [Associações de espécies de peixes em ambientes lóticos da bacia do rio Iguatemi, Estado do Mato Grosso do Sul]. [Article in Portuguese]. Acta. Sci. Biol. Sci. 25:361-367.

Súarez YR, Petrere M Jr, Catella AC, 2001. Factors determining the structure of fish communities in Pantanal ponds (MS, Brazil). Fisheries Manag. Ecol. 8:173-186.

Súarez YR, Petrere M Jr, Catella AC, 2004. Factors regulating diversity and abundance of fish communities in Pantanal ponds, Brazil. Fisheries Manag. Ecol. 11:45-50.

Tejerina-Garro FL, Fortin R, Rodríguez MA, 1998. Fish community structure in relation to enviromental variation in floodplain lakes of the Araguaia River, Amazon Basin. Environ. Biol. Fish. 51:399-410.

Tejerina-Garro FL, Mérona B, 2001. Spatial variability of biotic and abiotic factors of the aquatic habitat in French Guiana. Regul. River. 17:157-169.

Ter Braak CJF, 1986. Canonical correspondence analysis: a new eigenvector technique for multivariate direct gradient analysis. Ecology 67:1167-1179.

Tondato KK, Súarez YR, 2010. Temporal changes in fish species composition of headwater streams of the upper Paraguay and Paraná basins, Brazil. Acta. Sci. Biol. Sci. 32:179-284.

Valério SB, Súarez YR, Felipe TRA, Tondato KK, Ximenes LQL, 2007. Organization patterns of headwater-stream fish communities in the Upper Paraguay-Paraná basins. Hydrobiologia 583:241-250.

Welcomme RL, 1985. River fisheries. FAO Fish. Tech. Pap. no. 262. Food and Agriculture Organization of the United Nations ed., Roma, Italy: 330 pp.

Winemiller KO, 1996. Dynamic diversity: fish communities of tropical rivers, p. 99-134. In: M.L. Cody, J.A. Smallwood (eds.) Long term studies of vertebrate communities. Academic Press, Orlando, FL, USA.

Winemiller KO, Soner T, Shorman D, Cotner JB, 2000. Fish assemblage structure in relation to environmental variation among Brazos River Oxbow lakes. T. Am. Fish. Soc. 129:451-468. 